\title{
The Body as Archive: Will to Re-Enact and the Afterlives of Dances
}

\author{
André Lepecki
}

\author{
The idea of life and afterlife in works of art should be regarded with an entirely \\ unmetaphorical objectivity. \\ -Walter Benjamin, "The Task of the Translator" (Benjamin \\ I 996,254$)$
}

\section{Will to Archive/Will to Re-Enact}

aurence Louppe once advanced the intriguing notion that the dancer is "the veritable avatar of Orpheus: he has no right to turn back on his course, lest he be denied the object of his quest" (Louppe 1994,32 ). However, looking across the contemporary dance scene in Europe and the United States, one cannot escape the fact that dancers-contrary to Orpheus, contrary to Louppe's assertion-are increasingly turning back on their and dance history's tracks in order to find the "object of their quest." Indeed, contemporary dancers and choreographers in the United States and Europe have in recent years been actively engaged in creating re-enactments of sometimes well-known, sometimes obscure, dance works of the twentieth century. Examples abound: we can think of Fabian Barba's Schwingende Landschaft (2008), an evening-length piece where the Ecuadorian choreographer returns to Mary Wigman's seven solo pieces created in 1929 and performed during Wigman's first U.S. tour in I930; of Elliot Mercer returning in 2009 and 2010 to several of

André Lepecki is associate professor in the Department of Performance Studies at New York University. In 2009 he was a resident fellow at the Institute of Interweaving Performance Cultures, Freie Universität (Berlin). He edited Of the Presence of the Body (Wesleyan University Press, 2004), The Senses in Performance (with Sally Banes, Routledge, 2007), and Planes of Composition: Dance Theory and the Global (with Jenn Joy, Seagull Press, 2010). His book Exhausting Dance: Performance and Politics of Movement (Routledge, 2006) has been translated into six languages. Currently, Lepecki is working on a book on dance and sculpture and co-curating an archive on dance and the visual arts for the Hayward Gallery. He has given talks at Brown University, Princeton University, Le centre national de la danse, Museo Reina Sofia, Haus der Kulturen der Welt, and the Museum of Modern Art, among other venues. His co-curatorial and directorial work on the re-doing of Allan Kaprow's I8 Happenings in 6 Parts received the International Art Critics Association Award for "Best Performance" (2008). 
Simone Forti's Construction Pieces (1961/62), performing them at Washington Square Park in New York City; or Anne Collod's 2008 return to Anna Halprin's Parades and Changes (1965), among many other examples. We can name as well conferences and symposia in Europe ("re.act.feminism," Berlin, 2009; "Archive/Practice," Dance Archive Leipzig, 2009) or in the United States ("Re-constructions and Re-imaginations," Performance Space 122, New York, 2009) dedicated to the theme of re-enactment in contemporary dance and performance, as well as a whole festival at Kaai Theater Brussels in February of 20ro, entitled Re:Move, dedicated to re-enacting and archiving in contemporary dance. And, we can think of the three choreographers I will be addressing in this essay: Julie Tolentino's intensely corporeal archival project The Sky Remains the Same (an ongoing project initiated in 2008); Martin Nachbar's Urbeben Aufbeben (2008), in which the German choreographer dances Dore Hoyer's Affectos Humanos (1962/64); and Richard Move's many returns since the early I99os to several of Martha Graham's dance works (as well as to Graham's body).

Thus, turning and returning to all those tracks and steps and bodies and gestures and sweat and images and words and sounds performed by past dancers paradoxically becomes one of the most significant marks of contemporary experimental choreography. With this question of returning as experimentation-of choreographically experimenting whether by turning back or in turning back dance may nevertheless still escape Orpheus's curse of being frozen in time. While the recent interest in re-enacting in dance parallels a similar one in recent performance art, and while in the visual arts the term "archival impulse" —of which re-enacting participates - was coined by Hal Foster to describe what he identified as "a pervasive" concern" (Foster 2004, 3), I propose that in order to probe re-enactments in dance as a mark of experimentation that defines contemporaneity, ${ }^{2}$ a concept must be introduced: a specifically choreographic "will to archive."

"Will to archive" echoes, yet differs from, Hal Foster's notion of "archival impulse" in contemporary art. Indeed, I would suggest that Foster's concept remains problematic for several reasons. Referring to an artist's "will 'to connect what cannot be connected," equivalent to "a will to relate" and "to probe a misplaced past" (Foster 2004, 21; emphasis added), Foster defines "archival impulse" as directly resulting from a current "failure in cultural memory" produced by our "society of control" (2004, 2I-22, 22n60; emphasis added). Ramsay Burt, writing on "recent dance performances that have used, cited, or re-appropriated historical material for new purposes" (Burt 2003, 34), similarly invoked, one year prior to the publication of Foster's essay, this double articulation between cultural memory lapses and current shifts from discipline societies to societies of control. Burt describes how "the effect of this shift from discipline towards control, a move that is particularly difficult for traditional dance institutions, can be seen at work within dance performances that use historical material" (35). This would seem like a theoretical move similar to Foster's. However, what I find crucially different in Burt's more nuanced approach to re-enactments is how he understands this "effect" as a "reactive use of history" (37; emphasis added). Searching for nonreactive modes of activating performative approaches to history, Burt finds such approaches in dance re-enactments of the early 2000 s where an active (rather than reactive) and generative (rather than imitative) approach to 
"historical material" led dance re-enactments to resist "the disciplinary and controlling structures of repressive, representational regimes" $(39)$. $^{3}$

Burt's identification of nonreactive forces in recent dance re-enactments opens the possibility for critiquing one crucial component in Foster's "archival impulse": the supposedly "paranoiac" element in contemporary subjectivity wishing to connect to pasts that have been "misplaced" (Foster 2004, 22-23). When considered alongside Foster's already problematic understanding of pastness as locatable (spatialization of the past), his association of an artistic impulse to archive with a specific mental condition (psychologization of an artistic project) raises a few questions. Is it at all possible to affirm a past that is not always already "misplaced"? Is it possible to affirm any memory (cultural in particular) that does not somehow already "fail" to be fully present, and fully connected to the present? Is the paranoiac the only subject who can "connect"? Is archiving a paranoiac process about connecting with the past or is it, as Foucault so beautifully suggests in The Archaeology of Knowledge (I972), a system of transforming simultaneously past, present, and future- that is, a system for recreating a whole economy of the temporal?

I will address Foucault's proposals on archive in depth later in this essay, when discussing the work of Martin Nachbar. For now, it is important to note that when faced with Foster's model, one fact remains: it is the archive itself-either as memory (cultural or personal) or as bureaucracy (cultural or political) - that predicates, from the start, its own onto-political performance as one of endless memory "failures"-thanks to its constitutive (and unavoidable) acts of exclusions and misplacements. By dictating what deserves a place in it, and what should be excluded from it, by determining what is to be properly filed and what is (purposefully or inadvertently) to be "misplaced"in it, the archive reveals itself as a true Foucauldian dispositif, "distributing the visible and the invisible, generating or eliminating an object which cannot exist without it" (Deleuze 2006, 339). It is important to note that despite the archive's onto-political capacity to "command" and to set-up a whole system of "domiciliation" (Derrida I995, 2) of its objects; despite any pervasive and current condition of historical alienation based on, but also producer of, failed and disconnected memories; despite the current transition from disciplinarian societies to "control societies" in contemporaneity, ${ }^{4}$ the fact is that not all contemporary art-nor even art aimed at "connecting"-is propelled by and toward the archival. Moreover, it remains problematic to assign to works driven toward the archive an "impulse" coming from a specific subjectivity (even if this subjectivity does not describe a factual psychological trait of an artist but the general mode under which an artist operates under such an "archival impulse").

Writing on re-enactments in recent performance art, Jessica Santone advanced another critique to Foster's concept of "archival impulse." Correctly stating that the question at hand is not of a "past that is incomplete" (as Foster suggests) but of a "history that is incomplete" (Santone $2008, \mathrm{I47}$ ), for Santone the archival question proposed by re-enactments would be that of investigating the political-performative force of the (f)act of mediation in performance. Understanding re-enactments as a performed mode of criticality in relation to performance's inevitable and tense relations with its own his- 
toricity, Santone views re-enactments as performative modes of theorizing performance art's paradoxical relation to the document-echoing Rebecca Schneider's provocative notions of re-enactments as "counter-memory" and "re-documenting" (Schneider 200I). My position differs from both Foster's and Santone's, and in one crucial aspect I will make clear in a moment, differs also from Burt's. With the expression "will to archive in contemporary dance," I am proposing an alternative affective, political, and aesthetic frame for recent dance re-enactments-as well as for their relations to archival forces, impulses, or systems of command. Rather than "prob[ing] a misplaced past" in order to "connect so feverishly" what appears to us "so frightfully disconnected" in our historically alienated condition (Foster 2004, 2I-22) (as if historical and political alienation were a novelty in the history of Western societies); rather than creating a "work that repeats and multiplies an historical idea, inflecting its image through a nostalgic lens" predicated on a "drive to produce documentation"5 (Santone 2008, I47), I am suggesting that the current will to archive in dance, as performed by re-enactments, derives neither exclusively from "a failure in cultural memory" nor from "a nostalgic lens." I am proposing "will to archive" as referring to a capacity to identify in a past work still non-exhausted creative fields of "impalpable possibilities" (to use an expression from Brian Massumi [2002, 9I]). These fields of virtual "abstraction pertaining to the thing in general" (and to artworks in particular, I would add), these fields that "concern the possible" (Massumi 2002, 93), are always present in any past work and are that which re-enactments activate.

This activation is a matter of creating "compossibles" and "incompossibles"-two terms from Leibniz describing the infinite inventivity of the monad. As Gilles Deleuze explains, "compossibles can be called (I) the totality of converging and extensive series that constitute the world, (2) the totality of monads that convey the same world.... Incompossibles can be called ( $\mathrm{I}$ ) the series that diverge, and that from then on belong to two possible worlds, and (2) monads of which each express a world different from the other" (Deleuze 1993, 60). I am proposing that the current will to archive operates in a similar manner-one re-enacts not to fix a work in its singular (originating) possibilization but to unlock, release, and actualize a work's many (virtual) com- and incompossibilities, which the originating instantiation of the work kept in reserve, virtually. Significantly, and according to Deleuze, both modes of "possibles" in Leibniz operate as "recollections that try to become embodied" and "exert pressure" toward and on actualization (Deleuze I99r, 7r).

Because of these pressures toward embodied actualizations, every will to archive in dance must lead to a will to re-enact dances. Such an indissociable link means that each "will" acts upon the other to re-define what is understood by "archiving" and what is understood by "re-enacting." This redefining action is carried out through a common articulator: The dancer's body. As we will see in the three choreographic projects discussed in this essay, in dance re-enactments there will be no distinctions left between archive and body. The body is archive and archive a body. This is Julie Tolentino's explicit point of departure for her series The Sky Remains the Same. 


\section{The Sky Remains the Same}

American choreographer Julie Tolentino, in her series The Sky Remains the Same (2008 and ongoing), proposes her body as a living archive for works by several performance artists and choreographers, such as Ron Athey, Franko B, David Rousseve, and David Dorffman. I will refer to the first (and as of publication of this essay only) installment of the series, which I saw in Berlin in June of 2009. The piece Tolentino performed had a very simple and very effective compositional device. Tolentino chose one work by performance artist Ron Athey (Self-Obliteration $\#_{I}[2007]$ ) to archive onto (into?- the preposition remains uncertain in Tolentino's language, and this uncertainty must remain open) her body. This bodily archiving process takes place literally before an audience and literally as a re-enacting. As the audience enters the space, it finds Ron Athey and Julie Tolentino naked, on their knees, each on a raised metal platform and facing each other. Athey initiates the whole archival process by performing Self-Obliteration $\# I$ alone. On all fours, Athey starts combing the long blond hair of a wig that totally covers his face. After repeating this action for a few minutes, Athey removes the wig, reveals his face, and starts to pull out from under his shaved head's skin pre-placed pins and needles. Blood spurts immediately. In a kind of downward dog pose, Athey lets his blood drip on two large rectangular glasses placed on the platform-a deeply corporeal variation of drip- and action-painting. After bleeding and drip-painting with his blood, Athey starts to manipulate heavy panes of glass against his shaved head and naked body, smudging blood on the glass.

Photo I. Ron Athey performing Self-Obliteration \#I in The Sky Remains the Same (2008). Photo: Leon Mostovoy.

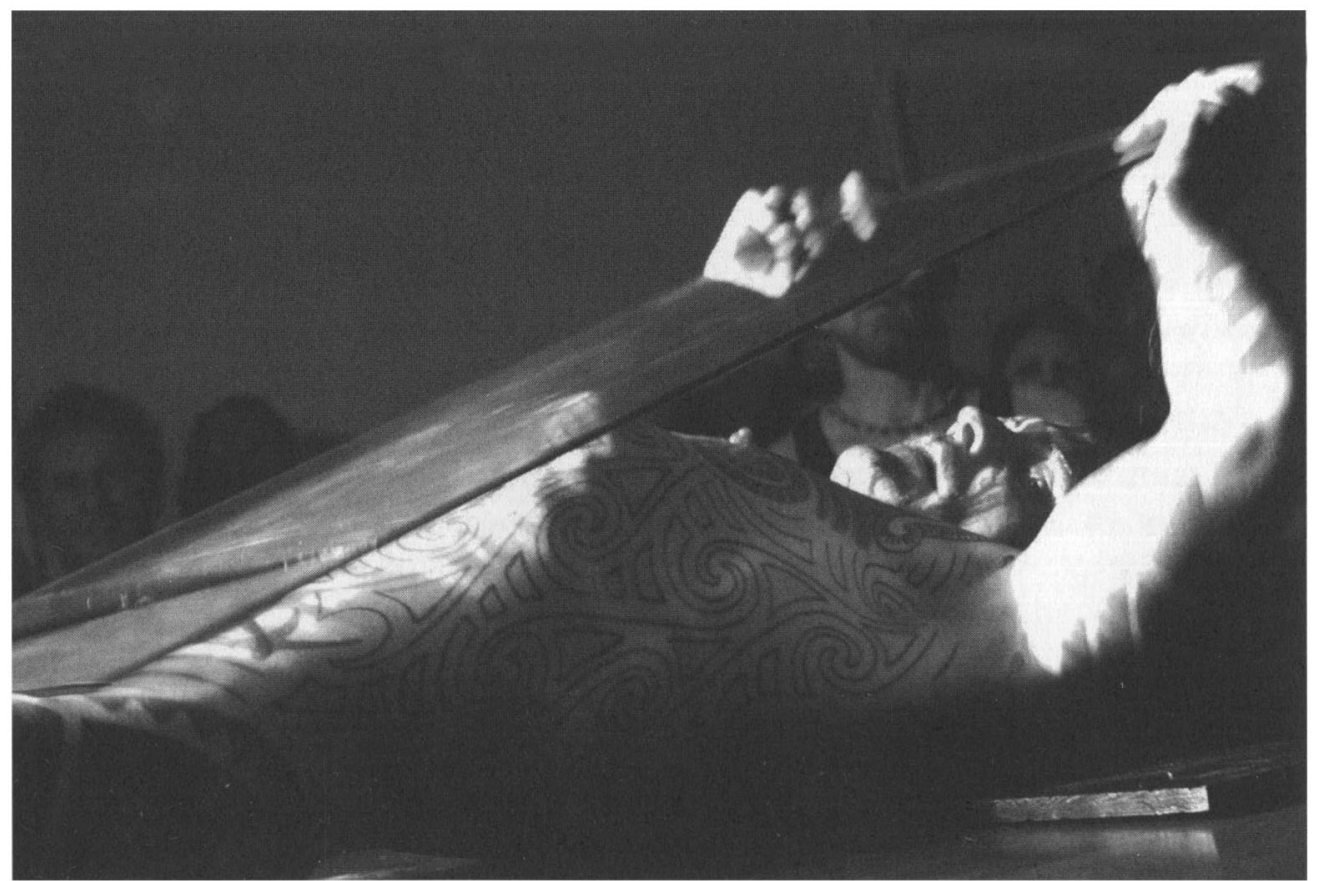


His excruciating effort now becoming apparent, as waves of tremors crisscross his body, Athey lies on his back and continues to manipulate the two panes of glass so that the blood staining them becomes imprinted back onto his skin. He trembles, blood keeps spurting, some in the audience squat down, some avert the gaze, some cannot take in the piece. Dizzy, I lower my head a few times. Yet, before Athey, a presence remains fully alert, poised, focused. A presence that will not avert full witnessing: the archiving body of Julie Tolentino. Her attentive stillness echoes the audience's silence-which is as thick as Athey's coagulating blood on the glass surfaces and on his skin. Self-Obliteration \#I ends with Athey placing each of the two smudged panes of glass vertically on slots at both ends of the platform. Athey puts on the wig again and lies down between the two blood-stained glasses framing him. The piece's final image uncannily mixes monument and meat. Throughout Athey's performance, Tolentino's still presence is complex and multiple in its functions: she becomes simultaneously an audience member, a student of the piece, an archivist, a potential archive, a performer, a partner, an enabler, a mirrorimage, a double, a differentiator, an assimilator ...

Photo 2. Julie Tolentino archiving Self-Obliteration \#I in The Sky Remains the Same (2008). Photo: Leon Mostovoy.

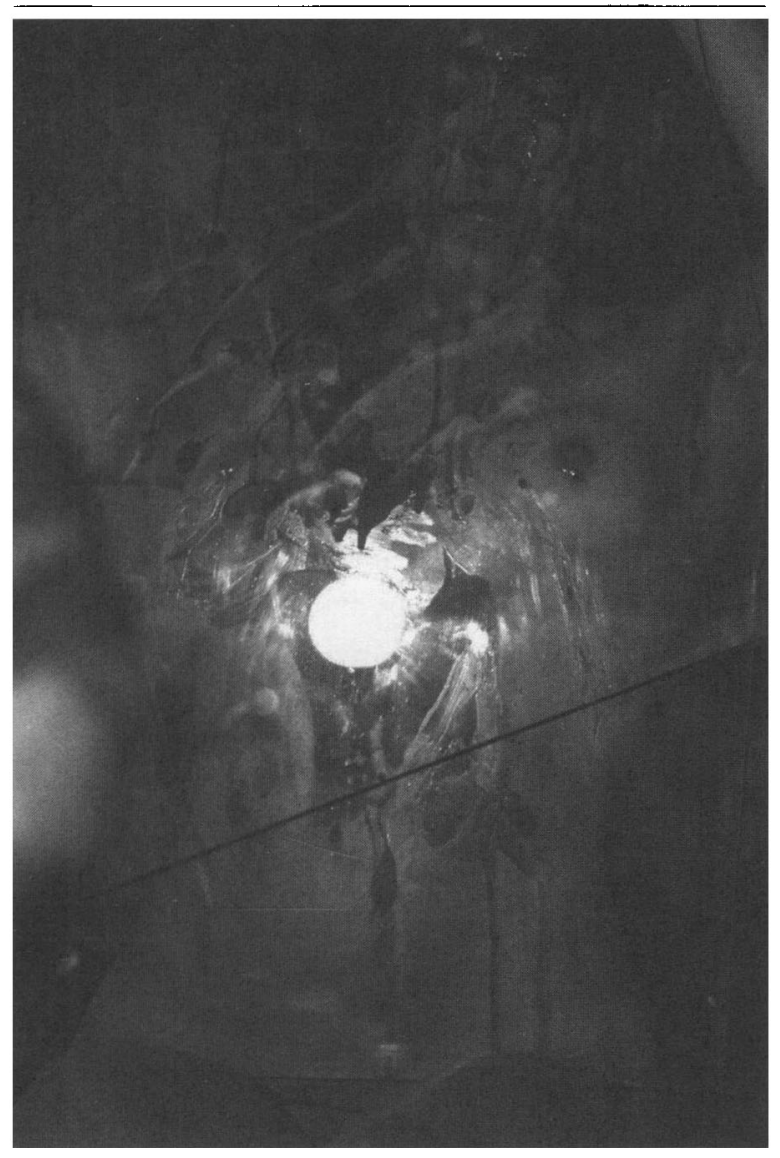

After completing his piece, covered in blood, panting, Athey gathers himself, goes back to the initial position, re-inserts the pins and needles in his temples, puts on the blond wig, grabs the comb, and re-starts Self-Obliteration \#I. This second time around, Tolentino joins Athey by performing the work along/before/with/for him. It is in and by the originating artist's non-Orphic, non-nostalgic, and certainly non-paranoiac return to a piece already performed, it is during and thanks to Athey's repetition, which is re-repeated by Tolentino, that the archiving of the work into/onto Tolentino's body takes place. Tolentino insists that what she performswhich could perhaps be more simply described as, for instance, "learning someone else's piece in front of an audience," or "imitating another artist's work of art," or "appropriating someone's work in front of an audience"-is not at all aimed at adding a new per- 
formance to her repertoire; rather, it is explicitly aimed at turning her body into an archive. As she wrote to me in February 20Io, "The series should only have one ending-meaning I offer to 'archive' [the works] for my own life's duration. The artists will make note of any changes to this duration within our contract. I plan to collect these archived works over the next years - another series of artists will be announced soon-however, focusing on these first. Challenging and exciting all."

Even if the sky remains the same, Julie Tolentino, collector of bodies, pieces, affects, and movements, will not. Through Tolentino's immediate re-enacting of a piece in order to corporeally archive it (for her life's duration), Athey's performance does not disappear into the past but zooms into the all-encompassing field of the possible defined by that indetermination that is a body. Athey's piece rushes into yet to be actualized afterlives, into the multiple, unmetaphorical, objective reality of the virtual incarnated in a body. ${ }^{7}$ Tolentino's body becomes the living archive of what, one day, will come back around-as it passes away. Dance.

Why does Tolentino need to call this particular and highly effective dramaturgical and choreographic processes "archiving"? Why this particular word, rather than "learning," "imitating," "copying," "appropriating," or simply "doing" another artist's work? Tolentino's emphasis on the word and the concept of "archive" is of interest, for the question of archiving onto/into one's body brings us back to the problems surrounding the cenotaphic affect in Western dance. Indeed, why recur to the most moving support, the most precarious support, a human body, in order to archive? Why add to the archival project the hyper-mobility and the series of paradoxical temporalizations proper to the body-this multivalent system of plural velocities and arrests, shadowed by the veilings and drifts in perception and in things, tricked by the parapraxes of language, cursed with bad memory, and grounded on the certainty of death? A possible answer can be found in the link Tolentino explicitly makes between archiving, excorporation and incorporation, and reenacting. This link explicitly foregrounds how Tolentino's will to archive is performed as will to re-enact, thus indicating the body as the privileged archival site. In its constitutive precariousness, perceptual blind-spots, linguistic indeterminations, muscular tremors, memory lapses, bleedings, rages, and passions, the body as archive re-places and diverts notions of archive away from a documental deposit or a bureaucratic agency dedicated to the (mis)management of "the past."With her emphasis on body-archiving, an endless mobility emerges as constitutive of this particularly transformative, particularly performative "archive without archive, where suddenly indiscernible from the impression of its imprint, Gradiva's footstep speaks by itself!" to use Derrida's phrase, where archive and dancing fuse in compossibilization (Derrida 1995,98 ).

The body as archivist is one thing. The body as archive is quite another. Tolentino's project performs an intriguing short-circuiting of all sorts of pre-conceptions about what a document is, while revealing what a body might have always been: a body may have always already been nothing other than an archive. If this is the case, it means that we need to understand current dance re-enactments as a mode of performance that has a consistency of its own. In a vein similar to Vanessa Agnew, when she proposed that re-enactments are "a form of affective history" (Agnew 2007,301), I would suggest that the performativity of 
the will to archive in The Sky Remains the Same considers and reveals how re-enacting is an affective mode of historicity that harnesses futurities by releasing pastness away from its many archival "domiciliations" - and particularly from that major force in a work's forced domiciliation: the author's intention as commanding authority over a work's afterlives.

Re-enactments transform all authored objects into fugitives in their own home. The paradox is that re-enactments, because they seem to return somehow to a past and an origin, need to bypass the arresting force of authorial authority, which would fix this return truly into an Orphic arrest. Thus the political-ethical imperative for re-enactments not only to reinvent, not only to point out that the present is different from the past, but to invent, to create-because of returning-something that is new and yet participates fully in the virtual cloud surrounding the originating work itself-while bypassing an author's wishes as last words over a work's destiny. This is one of the political acts reenacting performs as re-enactment: it suspends economies of authoritative authors who want to keep their works under house arrest. To re-enact would mean to disseminate, to spill without expecting a return or a profit. It would mean to expel, to ex-propriate, to excorporate under the name of a promise called giving. In other words, re-enactments enact the promise of the end of economy. They make dance return, only to give it awayas an author's blood spilled twice for the sake of self-obliteration.

\section{Urheben Aufheben}

German choreographer Martin Nachbar's Urbeben Aufbeben (2008) is an evening-length dance piece explicitly addressing the will to re-enact as will to archive. A choreographictheoretical reflection on the particular ways archival forces are deployed in and by dance, it is an artwork whose life is driven by an irresistible call placed by a 1967 film of German choreographer Dore Hoyer dancing her $1962 / 64$ solo series titled Affectos Humanos.

How does Nachbar answer this call (coming not from "the past," but from the present instantiation of an encounter between himself and a film excorporating $\mathrm{Affectos} \mathrm{Hu}$ manos) and start his piece? He enters into the stage by pushing in a blackboard, which reads: "Urheben Aufheben-An Applied Research." After positioning the blackboard

Pboto 3. Martin Nachbar in Urheben Aufheben (2008). Photo: Gerbard Ludwig.

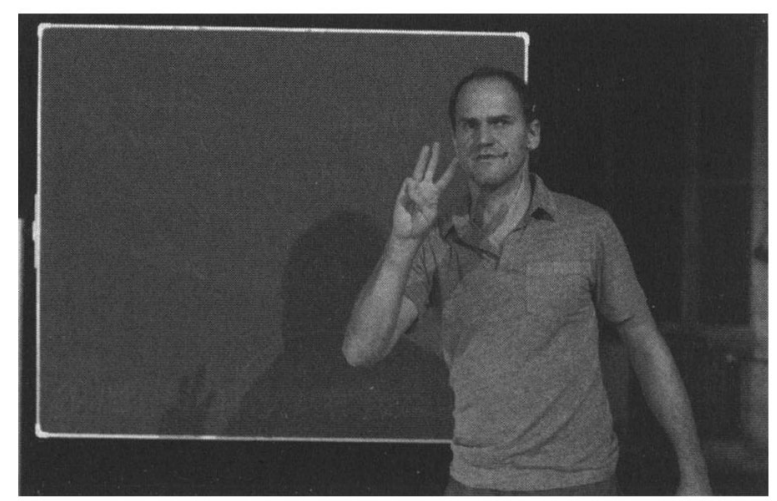

downstage left, Nachbar stands next to it, faces his audience and states: "Step one: Entering into the Archive."

How does he enter into the archive? By calmly walking a couple of steps more onto the stage and starting to run in wide circles backwards. In other words, Nachbar enters the archive by returning, like an anti-Orpheus. By running backwards in circles, only seemingly does he go nowhere- 
because by running in the same place, Nachbar defines a border, a lip of time. And what does Nachbar find in his backward turns as he turns to the archive and defines its contours? Literally affects: Affectos Humanos-the film shot in 1967 (the year Hoyer died). It is almost uncanny how Urbeben Aufheben explicitly invokes Spinoza - the philosopher who defined the body in terms of affects and who understood the body as a set of velocities, intensities, and capacities of affecting and being affected-in other words, the body as a dynamic system of excorporations and incorporations. ${ }^{8}$

So, Nachbar picked up something ("to pick up" is one of the meanings of the German word aufheben) from the virtual cloud of dance history, followed the path of that something, found Waltraud Lulev, a former Hoyer dancer who was authorized to teach the piece, and learned it from her, as best he could-even though, as she told him, he had the wrong body. Nachbar's re-enactment has a long history. In an earlier version titled Affects/Rework (2000), Nachbar collaborated with choreographers Thomas Plischke and Alice Chauchat, all members of the collective B.D.C. This earlier version included a solo by Plischke, a video of him shaving, the voice of Chauchat, and three danced "affects" performed by Nachbar from Hoyer's five. In the more recent Urbeben Aufbeben, Nachbar performs solo and dances four of the "affects" (Vanity, Desire, Hate, and Fear) while marking and describing the last one (Love). In both pieces, however, there is a similar point of departure: by picking up Hoyer's dances only to keep them corporeally, Martin performed a return - but one confounding the strict circularity of proper economy, since this return also suspended (another meaning of the word aufheben) Hoyer's authorial force by augmenting the force coming from the work itself. As Nachbar wrote to me about the meaning of the title of the piece, "Urbeben Aufbeben is a play with words and can mean three things: I. To pick something created up from the floor. 2. To keep it. 3. To suspend the notion of authorship." The whole evening is structured around Nachbar narrating how the process of creating the new work unfolded first as a search and then as research. His narrative is interrupted (or joined) only by the four dances already mentioned and the description/marking of the dance-affect Love.

At a certain point in his performance, as Nachbar summarizes the three steps he had to go through in order to get "into the archive," as he put it, he makes a profound statement. This is what he tells us at a certain point in the piece:

Ok, let's go back to the beginning: we had [the sections] "Entering the Archive," "Applied Recollection" and "Storehouse" [Lager]. Now, what happens, if I don't just visit the storehouse but try to push my body into it and at the same time, allow the storehouse to push itself into my body? Maybe the storehouse will be systematized and become an archive. And then the archive will become visible through my body. So, when these three elements connect and form a critical point: What will happen? What will come out at the other side of this point? ${ }^{10}$

A "critical point" is another name for "singularity," that is to say, another name for actualization, which in turn is "a kind of displacement by which the past is embodied only in terms of a present that is different from that which it has been" (Deleuze 1991, 7I). Deleuze's description of the actualization of singularities as embodiment is, in many ways, 
similar to Nachbar's description of how archival particles went through his body and how his body went through archival particles and this movement formed a critical point from which something else could come out. For Deleuze, what "comes out" of a singularity or critical point is, simply, an event." What would be the event Nachbar creates with his re-enactment of Hoyer's work? It is the event of compossibility: the creation of the conditions for Affectos Humanos to pass through new possibilizations that Hoyer could not offer to it, could not actualize, even as she authored the work. In other words, the event is to have Affectos Humanos pass through a compossible becoming. But how does Nachbar reach, or create, or drill, or summon this critical point - which is both choreographic and corporeal? As he tells us during the performance, he does so by creating a system of excorporations and incorporations, transmissions and alliances, between archives and bodies, and to such a degree that both archives and bodies start to fuse into one another to finally become each other. Let me repeat, and now emphasize, what Nachbar had just said to his audience: "Now, what happens, if I don't just visit the storehouse but try to push my body into it and at the same time, allow the storehouse to push itself into my body? ... then the archive will become visible through my body."

Pushing the body into the archive, pushing the archive into the body-a mutual metamorphosis conjuring up, creating, secreting, excreting, inflecting critical points where virtuals and actuals exchange place. Used as a metamorphic concept, Nachbar's understanding of archive resonates vividly with the concept of "archive" developed by Michel Foucault in The Archaeology of Knowledge. What is archive, for Foucault, in that book? He writes: "By this term I do not mean the sum of all the texts that a culture has kept upon its person as documents attesting to its own past, or as evidence of a continuing identity; nor do I mean the institutions, which, in a given society, make it possible to record and preserve those discourses that one wishes to remember and keep in circulation" (1972, I28-29). So the archive, for Foucault, is not a thing, not a recipient, not a building, nor a box, nor a filing system. Foucault adds: "It does not have the weight of tradition; and it does not constitute the library of all libraries" (130). Rather, the archive is "the general system of formation and transformation of statements" (r3o; emphasis added). And we must add here that for Foucault, "statements" are transformed by this "general system" into "events and things" (128, emphasis added). Similarly, choreography is also a dynamic system of transmission and of transformation, an archival-corporeal system that also turns statements-such as "Person I walks slowly along corridor, stops at entrance 5 secs, walks slowly in a straight line ..." (excerpted from Allan Kaprow's score for 18 Happenings in Parts [I959]); or "The left arm is extended sideways and drawn a little backwards, but in line with the pit of the body (excerpted from Pierre Rameau, The Dancing Master [1725]); or "Stand in 5th, right foot behind. Relevé on left foot with right leg in 2nd, single or double rond de jambe, and close right foot front" (excerpted from Joyce Mackie, Basic Ballet [r999])-into corporeal events and kinetic things. That is to say, because it is a system of transformation, the archive is in itself a critical point, a singularity-squeezing out actuals from the virtual cloud, and secreting back virtuals from the actuals; turning corporeal events into kinetic things, corporeal things into kinetic events.

But how can we access the archive, enter the archive, if the archive is not a "storehouse"- 
as Nachbar says during his piece, echoing Foucault-but indeed a system? The answer is: only choreographically. For if choreography knows something, it is that an archive does not store: it acts. And its actions take place primarily by delimiting zones of temporality and rhythms of presence-just as choreography must: "The analysis of the archive, then, involves a privileged region: at once close to us, and different from our present existence, it is the border of time which surrounds our presence, which overhangs it, and which indicates its otherness; it is that which, outside ourselves, delimits us" (Foucault 1972, 130; emphasis added). These zones, or regions, or dimensions form and transform not only our notions but our very experiences of time, presence, identity, alterity, body, memory, past, future, subjectivity. The archive as border becomes the vertiginous skin where all sorts of onto-political "re-writings" (Foucault 1972, 140) take place, including the re-writ-

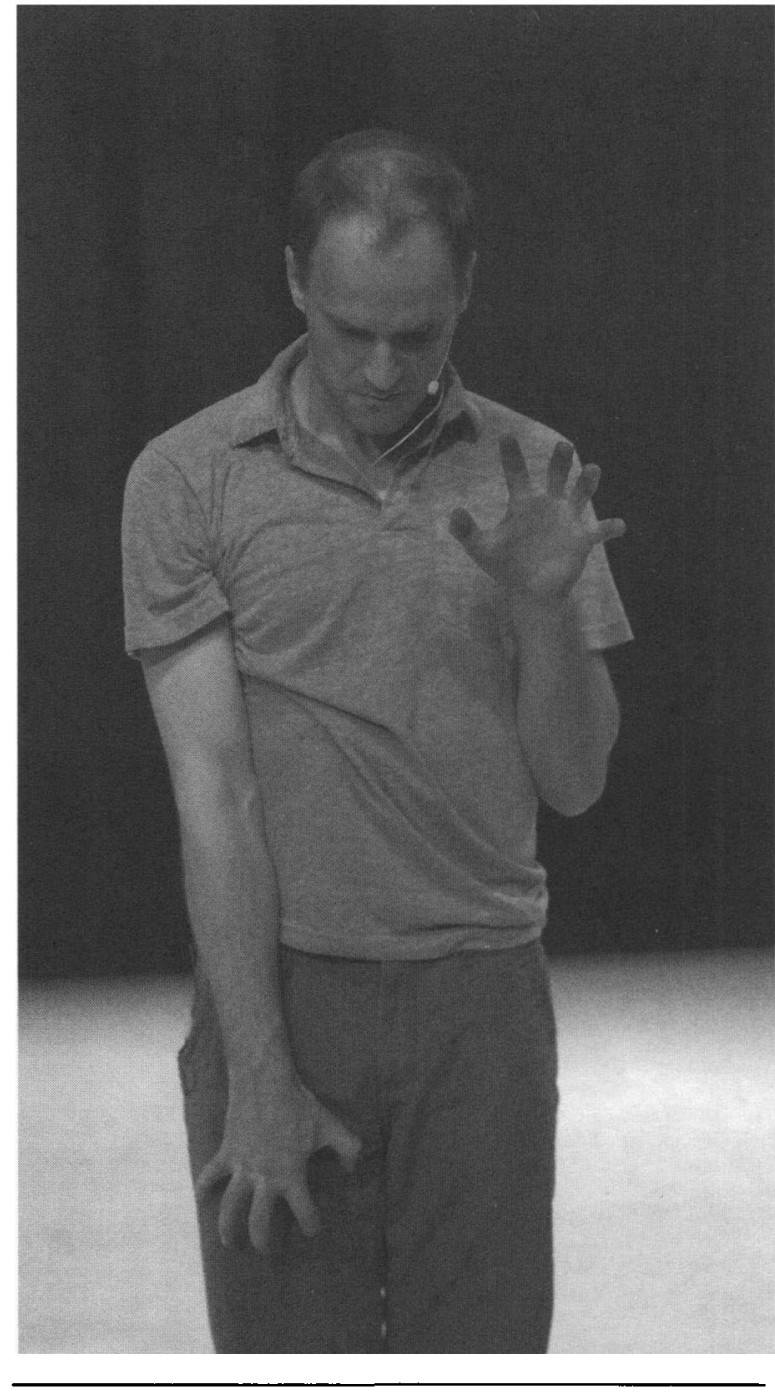

Photo 4. Martin Nacbbar in Urheben Aufheben (2008). Photo: Gerhard Ludwig. ing of movement, including the re-writing of the archive itself. As Nachbar tells us halfway into Urbeben Aufbeben, "I go into the archive and a difference emerges, the archive gets messed up. At the same time it becomes visible through my body. ... My body makes the archive visible and at the same time, creates this difference."

Like the body, like subjectivity, the archive is dispersion, expelling, spilling, differentiation; a foaming and a forming and a transforming of statements into events, of things into words, and of virtuals into actuals (and vice versa). If, in The Archaeology of Knowledge, Foucault is primarily concerned with the analysis of the systematic transformations endured by "statements" and "discursive practices" (1972, 135), his discussion of archive includes moments where more embodied practices make an appearance, and where identity and subjectivity are clearly invoked as central to the archival system of transformation. Thus, Foucault mentions how the archive "dissipates that temporal iden- 
tity in which we are pleased to look at ourselves" and "it establishes that we are difference" ( $13 \mathrm{I}$; emphasis added). Identification, identity, notions of selfhood and even of perception and self-perception - as much as statements and discourses-endure the same process of transformation established by the archive's operations. Moreover, the self that is referred to in the expression "our selves" is cast as essentially performative and theatrical since the archive establishes that "our selves [are] the difference of masks" (I3I). This multiple and multiplying active differentiation, operating in statements and discourses, but also in identity, in ways of looking at ourselves and of understanding our selves as masquerade, is simultaneously subjective, ontological, and performative. Its discovery: "That difference, far from being the forgotten or recovered origin, is this dispersion that we are and make" (Foucault 1972, 131; emphasis added).

Let's consider for a moment the political implications of this making-dispersion that, for Foucault, we already are. Let's consider it in the particular field of choreography and through the particular practices of dancing in this field. Finally, and following Foucault's suggestion, let's consider the question of dispersion not in relation to a misfiled, misarchived origin but as the onto-political performativity of the archive, that which turns it into something other than a storehouse or cenotaph of past movements.

Gabrielle Brandstetter, in her essay "Choreography as Cenotaph" (Brandstetter 2000, I02), used a term that I have been using so far in this essay without defining it properly. Since this term allows for identifying non-melancholic, or non-lamentational, kinds of affect in the current will to archive as will to re-enact in experimental dance, I would like to push it now to its conceptual limits since it will help articulate all three projects under discussion in regard to this body-archive. The term is "excorporation," and Brandstetter proposed that dance happens (we can say, that dance dances) thanks to an ongoing dialectic of incorporations and "excorporations." I would like to take Brandstetter's proposition further and add that in such dialectics, all sorts of bodies (human, textual, architectural, representational) involved in the (f)act of dancing expel and internalize each other's forces, surfaces, velocities, and modes. In this circulation and exchange, what turns and returns, and what in this movement is perhaps surpassed, transformed, dispersed, is the melancholic or cenotaphic notion that dance is that which only passes away. Instead, to understand dance as a dynamic, transhistorical, and intersubjective system of incorporations and excorporations is to understand dance not only as that which passes away (in time and across space) but also as that which passes around (between and across bodies of dancers, viewers, choreographers) and as that which also, always, comes back around. Dance is the passing around and the coming around of corporeal formations and transformations by means of excorporations and incorporations of jets of affects (or jets of affective singularities). Thanks to transformative exchanges of steps and sweat, thanks to ongoing transmissions of images and resonances, choreography allows dancers to turn and return on their tracks in order to dance via ex- and incorporations. This kind of dynamics founds a particular economy, where bodies intertwine, or intermingle, across time-in an endless chain of reciprocal emissions, transmissions, receptions, and exchanges of times, gestures, steps, affects, sweat, breathing, and historical and political particles. Under this transformative system of excorporations and incorporations, the afterlife of dance works gains a new 
objectivity, bypassing melancholia as its main affect, its main drive or nostalgic impulse. What exactly do bodies exchange in this non-melancholic choreographic economy of transmission? Again, they exchange modes of compossibilization and of incompossibilization of a supposedly past work, which is never, ever, dead. Instead it is always haunting.

\section{"Dragging Martha Back from the Dead"}

With Foucault's notion of a transformative archive, and our notion of dance as a system of incorporating excorporations and excorporating incorporations, I would like to invoke the work of a choreographer who has a very different approach to archiving than the previous two: Richard Move. Precisely because Move's well-known performances, based on his uncanny and humorous impersonation of Martha Graham, did not originate explicitly as "archival" investigations (as opposed to Tolentino's or Nachbar's), they become a particularly interesting case of yet another "will to archive" in dance.

In 1996, in a nightclub in Manhattan's meatpacking district called Mother, Richard Move began his now famous performance skits where he transformed himself into Mar-

Photo 5. Martin Nachbar in Urheben Aufheben (2008). Photo: Gerhard Ludwig.

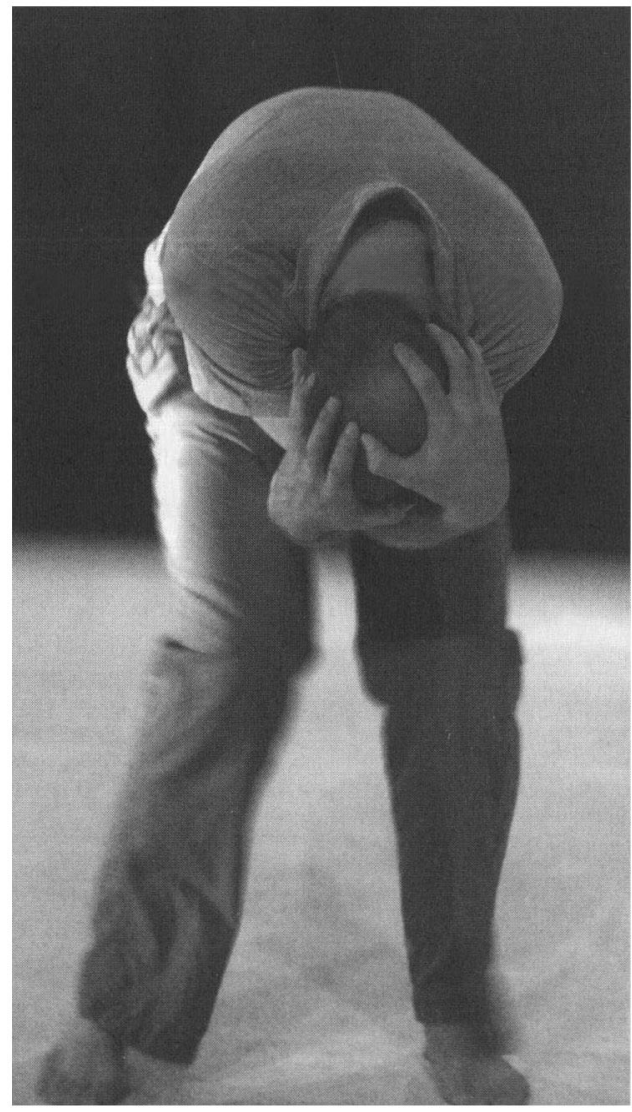

Photo 6. Rehearsal shot of Dore Hoyer in "Angst" from Affectos Humanos (1962). (C) Jacques Hartz, courtesy Deutsches Tanzarchiv Köln.

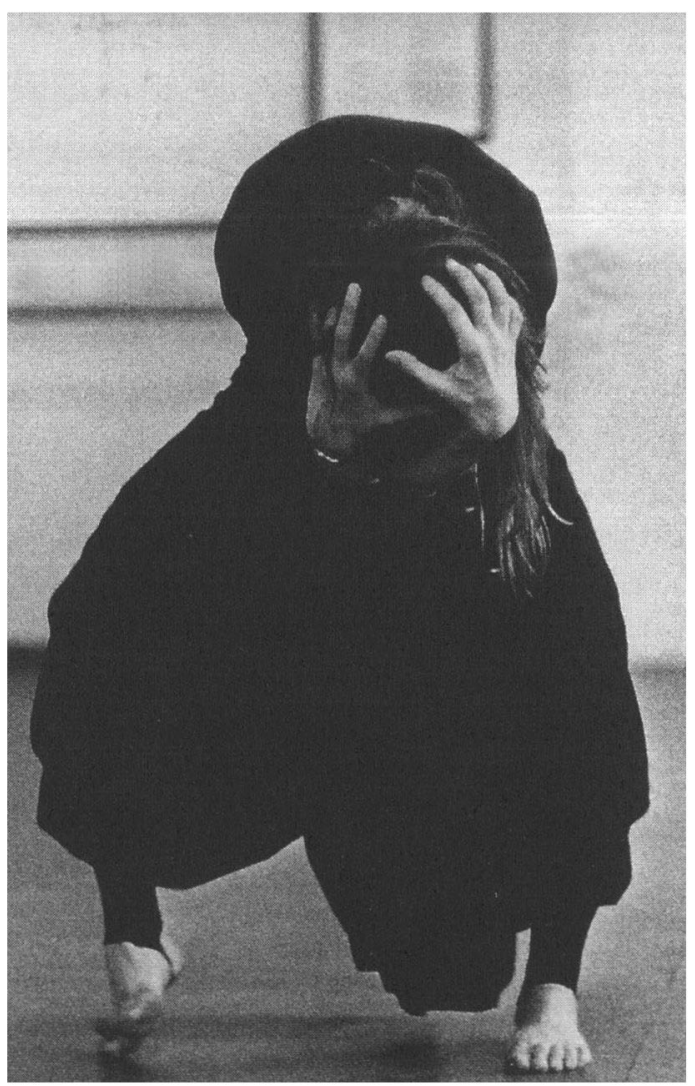


tha Graham. Titled "Martha@Mother," the show initially started as a solo performance, evolving throughout the decade into ever more elaborated forms, including the New York City Town Hall event in 2000 where Move presented alongside his rendition of Graham's seminal Lamentation a re-enactment of Graham's forgotten 1962 creation Pbaedra. The event also included a now famous dialogue between Move's Martha Graham and Merce Cunningham himself, in what was perhaps the last time Cunningham performed on a stage before an audience.

In a recent conversation, Move mentioned that what initially attracted him to Graham was the sheer force of her presence and the outrageous theatricality of her "Greek" pieces, which by the early iggos had become completely outmoded, derided, and neglected by contemporary dance. As he told me in a conversation, "Graham had been dismissed as passée" (conversation with the author, November 2009). But, despite her relegation to a passed past, Graham's dances, her stage and public persona, her force (Move talks of her "eroticism"), her words exerted an irresistible pull over Move. Graham was a call Move could not resist.

It is interesting to see how Move's incorporation/impersonation of Martha Graham was very early on perceived not only as a drag impersonation but also as a kind of haunting. William Harris, writing in a New York Times review of Move's performances at Mother, explicitly introduced the question of haunting right at the core of Move's re-enactments: "Despite forensic evidence, the modern-dance pioneer Martha Graham did not die in I991. She can be found performing, name dropping and introducing guest choreographers the first Wednesday and Thursday of most months at a club in Manhattan's meatpacking district" (Harris 1998, 10). In an inspired rhetorical move, Harris describes Richard Move's performance as "dragging Martha back from the dead" (Io).

Photo 7. Richard Move as Martha. Photo: Josef Astor.

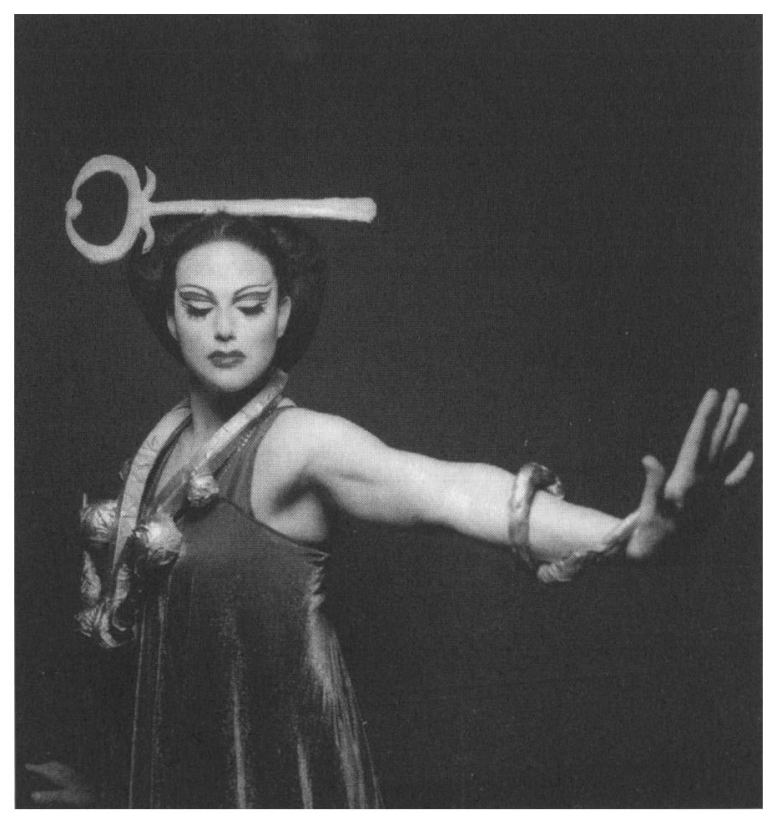

Haunting, understood as a sociological effect that unleashes historicity, adds an affective component to the current politics of re-enacting in dance. Avery Gordon theorized on the performative and political force of what she called "ghostly matter" to propose that "such endings that are not over is what haunting is about" (Gordon 1997, 139). This inconclusiveness in endings, the fact that matters are always unsettled and, moreover, demand objectivity when unleashing their afterlife, is what Move understood, and captured, when he found in Graham a force that was incontrollable, 
even after her death. Graham's "ghostly matter" is an excorporating cloud traveling across time, across space, across genders, across historical periods, across legal copyright barriers, and bursting through the supposed fixity of the past into a transgressive revelation of its powerful actualizations, via a transformative incorporation in Richard Move's performances.

Move's re-enactments may have started as intelligently crafted amusement. But as Roger Caillois once warned, one has to beware when playing ghost, lest one becomes one. The fact was that Graham's and Move's exchanges of ex- and incorporations generated a powerful haunting that transcended the realm of entertainment and entered deeply into a much broader and complicated social field. Move's Graham disturbed temporal economies, affective economies, as well as authorial economies. Having "picked up from the ground" (to use the expression Nachbar used to talk about his work of re-enacting Hoyer's Affectos Humanos) ghostly matters excorporated by a name, a force, a corpse, a singularity, and a system of affect named Martha Graham, Move's body incorporated and then started to perform a radical disturbance for those deemed to have exclusive control over the afterlife not only of artworks but of a dead author's will. Harnessing ghostly matters - matters that by definition strive to escape laws of property and propriety-Move started to incorporate an archive that countered authoritative economies of authorship. Not surprisingly, soon after he started his performances at Mother, Move received from the Graham Company lawyers a "Cease and Desist" letter accusing him of copyright infringement and misleading the public. Move's first performances as Martha Graham coincided with the beginning of a long period where a fierce litigation over Graham's repertoire was being unleashed. As Selby Schwartz, in a recent essay on Move's work, noted: "the rights to Martha's voice, and the authority to represent her character, became the focus of intense litigation that lasted for a decade; for a few years, the dancers in her company were legally prohibited from performing the pieces in repertoire" (Schwartz 2010, 65). This is an ironic twist: before an author's corpse, it was the repertoire (which Diana Taylor famously "opposed to the supposed stable objects in the archive" as all that "enacts embodied memory" [Taylor $2003,20]$ ) that had been frozen, controlled, and disciplined.

A legal blackout lasted four years when the entire Martha Graham repertoire was forbidden from being performed. Between 2000 and 2004 " it was illegal for Graham dancer's to perform works in repertoire (Ron Protas held the rights); the situation was so dire that the entire Company had been disbanded. The dancers were laid off, the lawyers kept fighting ... For four years, Richard Move was more or less the only person in the world publicly performing Martha Graham's choreography" (Schwartz 2010, 75). Meanwhile, Move's own system of transformation, composed by both dragging and re-enacting, was creating, away from the institutional struggles over Graham's corpse, a powerful corporeal and affective archive —an archive that could unleash Martha's voice, as well as her body, presence, dance, eroticism, creativity, and works. Move responded to the lawyers' demand for him to cease his becoming Martha by changing the photo in the show's poster from Graham's to him and by adding a short disclaimer: "This event is in no way connected to or sponsored by the Martha Graham Entities"-where "entities" covered the school, 
company, building/studio, ballet licensing, estate, personal effects, etc. In other words, it covered all but ghostly matters, those impalpable virtuals willing actualization.

As Graham was becoming Move, Move was becoming Graham: "I'm filled by her," says Move to Schwartz (Schwartz 2010, 68). Having transformed his body also into Graham's body, and having started to perform re-enactments of several of Graham's pieces (Move described his approach to these re-enactments as "deconstructions or synoptic re-inventions," the major exception being Phaedra, which would be his most faithful rendition of an originating piece), Move did not attract only the attention of policing lawyers. Move's body literally became an attractor of Graham's most intimate collaborators, friends, and former dancers. And, as an attractor-that is, a critical point-he started to be treated by them as an archive. Just as with Tolentino, a body was picked to serve as archive. Just as with Tolentino, it was clear that dance can only find its proper archival site onto/into a body - the body understood as an affective system of formation, transformation, incorporation, and dispersion. On Move's second show at Mother, Bertram Ross, iconic former dancer with the Martha Graham Company, approached Move and said: "You need to change your lipstick. Martha would use a much darker tone" (Move, personal communication, November 2009). With only black and white photographs of Graham's Lamentation (I930) and a I94I artificially colored film that cannot provide accurate details such as a lipstick's actual hue (the famous purple tube dress appears greenish in this "colorized" film, which was "corrected" in the 1960s but again artificially), there was no way this piece of information could be gathered from the documents (most of the important film documents of Graham's works Dancer's World, Appalachian Spring, Night Journey are all in black and white). So it was gathered via a relational act, a gift, which in giving, transformed at that moment Richard Move's body into an affective archive; or as Schwartz writes, "a repository for an authentic history of Martha" (75). I would just replace "authentic" by "affective" in Schwartz's observation, as more and more "donations" would come from former dancers correcting some detail in Move's gesture, posture, or steps; or giving him personal items that have been strongly linked to Graham. Since his first performances, old videotapes in the ever more decaying and neglected archives of the company would be secretly smuggled out by company members and lent to Move so he could continue his research and compose his short re-enactments. Storytelling, smuggling, and giving - all generating an affective historiography to collectively help drag Martha from death and to drag Move into creative returns-not to the past, but to the compossible and incompossible zones defined by Martha Graham, her works, and her friends. Once into the field of ghostly matters, it is very hard for a kind of community not to come into being - a community without ends.

In April of 2006, on the occasion of the Graham Company's eightieth anniversary, Move performed with the company as Martha Graham as a part of their opening night gala at the Skirball Center, in New York. Move performed both a monologue written for the occasion and danced with Desmond Richardson a duet excerpt from a rather obscure ballet from 1965, Part Real-Part Dream. Unlike his previous "deconstructeddistillations," this was an "official" and more conventional revival, coached by the senior 


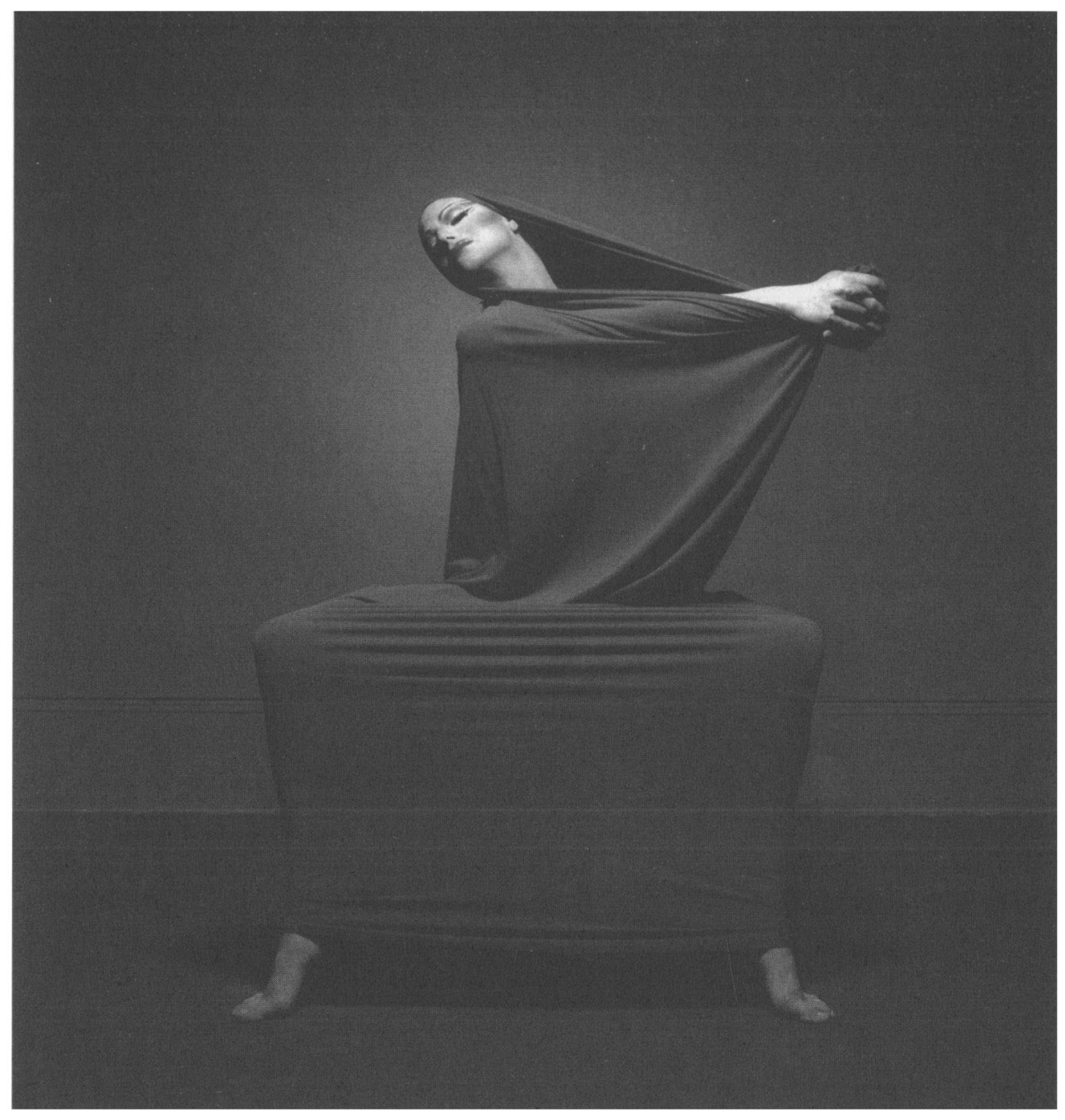

Photo 8. Richard Move's re-enactment of Martha Graham's Lamentation. Photo: Josef Astor.

company members, under the artistic director, Janet Eilber. Then, in 2007, Move was commissioned to create a new dance for the company. This new work is now in the Martha Graham Company's repertoire and tours internationally. But since Move is also Martha and Martha is now also Move, one wonders about the authorial status of such a piece. As Schwartz observes, "it is a great triumph of drag performance history that Richard Move, with his minimal Graham training and go-go career, with his 6' 4 " frame and Jackie 6o's tastes, who could say dismissively that Graham's Greek pieces were 'total soap opera,' seemed like the most reliable repository for Martha Graham's career" (2010, 76). But I would suggest that the affective force of the ghostly turned Move into something much more powerful than a "repository": it turned him into a corporeal archive, a system or zone where works do not rest but are formed and transformed, endlessly-like ghostly matters. Or simply, like bodies. 


\section{Will to Archive/Will to Re-Enact/Again (and Back)}

I hope to show through the works of these three, very different, choreographers how what I called "will to archive" taps into a work's very concrete and very real virtuality-which remains fully contemporary in its demands for actualization. It is with the identification of a creative (yet virtual) potential already lodged in the artwork itself that I differ from one main aspect in Ramsay Burt's analysis of recent re-enactments. In the same essay discussed earlier, Burt describes the political force in re-enactments as deriving from artists "conceptually framing their inevitable failures to be faithful to an original," where "what is significant is not the fact of these failures but how they are framed"(Burt 2003,38; emphasis added). Contrary to Burt, and with the help of the three modes of re-enactments just discussed, I am proposing that failure remains a false problem in relation to the will to re-enact (in the strict sense given in this paper, that is, as an unmetaphorical actualization of an artwork's afterlife). For, to posit "inevitable failures" as (f)acts of unfaithfulness presupposes that an "original" is always felicitous, whole, and faithful to its putative originary (self-)integrity. Rather than think of re-enactments as conceptual frames for a choreographer's "inevitable" failed efforts to succeed in copying an original fully, I would like to propose the will to re-enact as a privileged mode to effectuate or actualize a work's immanent field of inventiveness and creativity. This proposition implies that we must treat any artwork, for instance a choreographic piece, as a somewhat autonomous being in its planes of composition, expression, and consistency, while to posit the artwork's autonomy implies recognizing a specific capacity in any choreography to appeal, call, or even demand for actualizations. In this move, I am agreeing with Silvia Benso's "ethics of things," which understands how "works of art, although humanly made, are self-sufficient. Their selfsufficiency erases the presence of the artist in them, in order for the work to be released to its pure self-subsistance" (Benso 2000, I04). Benso's Heideggerian project for an ethics of things can be supplemented by a Deleuzian politics of becoming: one where the "selfsubsistance" of any concrete actualization of an artwork is constitutively composed by the reality of the virtual cloud surrounding it-a virtual cloud activating incompossibles and compossibles already in the work but that may not have been actualized yet, may not have found a corporeal manifestation in the work's "original" expression. Actualization is also different than reinvention: it is rather an invention whose possibilization nevertheless rests with the work itself. It is the task of the re-enactor to pick up a work's virtual (yet very concrete and specific) forces and to actualize that work's always incomplete, yet always consistent, multiple, and heterogeneously singular plane of composition. ${ }^{12}$

It is invention in all its powers that leads me toward the need to replace psychoanalytically charged words such as "impulse" (Hal Foster) or "drive" (Santone) as qualifiers for the artistic desire to archive by the more performative expression "will to archive." I prefer "will" because it names the differential force of augmentation inextricably bound to creation thanks to the specifically choreographic fact of re-turning. I am following here Deleuze's identification of the deep connection between "will" (as positive, nonreactive force) and "creation," one that takes place due to a kinetic articulator: to return. Indeed, for Deleuze, return is the movement that posits a constitutive (creative) difference in 
repetition, thus "bring[ing] about the equation willing=creating" (Deleuze 2006, 69). Here, we also return to the beginning of this essay and can finally understand why Laurence Louppe's assertion does not hold: return is what dance must do precisely because return is the essential creative differential repetition that frees dance and dancers from Orpheus's curse. This is Mark Franko's insight on dance "reconstructions": they address and foreground a fundamental theatrical-theoretical "obsession" with repeatability that may very well be the onto-political (differential) contemporary mark of dance (Franko I989, 73). In a vein similar to my own argument, this differential mark is what moves Franko to propose the term "construction" as an alternative to reconstruction. What must be made clear now is that re-enactments, as "will to archive," invest in creative re-turns precisely in order to find, foreground, and produce (or invent, or "make," as Foucault proposed) difference. This production of difference is not equivalent to the display of failures by re-enactors to be faithful to original works-but the actualization of the work's always creative, (self-)differential, and virtual inventiveness. Thus the political imperative resulting from the will to archive as will to re-enact: difference with repetition, repetition because of difference- both operating under the sign of creation and never of failure, unleashing history and dances toward afterlives where, as Benjamin so beautifully wrote, "the life of the original attains its latest, continually renewed, and most complete unfolding" (Benjamin 1996, 255).

In this light, recent dance re-enactments could be seen not as paranoid-melancholic compulsions to repeat but as singular modes of politicizing time and economies of authorship via the choreographic activation of the dancer's body as an endlessly creative, transformational archive. In re-enacting we turn back, and in this return we find in past dances a will to keep inventing.

\section{Notes}

I. Relevant artists working on re-enactments include Lilibeth Cuenca, Marina Abramovic, and David Weber-Krebs.

2. Re-enactments are significant in such a way that one should ask whether this insistence to return (this will to re-enact) might be that particular trait that allows dance to define itself precisely as contemporary. For this strong characteristic of some recent experimental dance, which many seem to consider a distinctive trait of its contemporaneity, is in itself already a kind of return (even if unacknowledged) of an earlier wave of re-enactments in the early I 980 s. The privileged term at the time was "reconstruction," and Mark Franko, writing in 1989, described the "recent reconstructions in the 1980 " as "an impetus to contemporary experimentation in choreography" (Franko 1989, 59nio; emphasis added). In the same essay, Franko quotes a 1983 review by Sally Banes where she remarks on "the current mania for reconstruction" $\left(57^{n} 3_{3}\right.$. More uncannily, Franko opens his essay by mentioning Suzanne Linke's 1988 reconstruction of Dore Hoyer's Affectos Humanos-the same piece that Nachbar will (re)turn to in his Urbeben Aufbeben (2008), discussed in this essay.

3. The notion of dance re-enactments' capacity to resist can already be found in Mark Franko's essay on reconstructions in experimental dance in the 1980 . Franko proposed the term "reinvention" to characterize how "poised between the apprehension of the object and the creation of the object, [reconstructions] can both serve cultural critique and foster new creativity" (Franko 1989, 73). Curiously, in the late 1960 s Allan Kaprow had proposed both the term and the practice of 
reinvention as an imperative to all re-creations (whether done by himself or others) of his happenings and events, using similar arguments. See, for instance, Rosenthal (2008).

4. The transition between societies of discipline and current societies of control is theorized by Gilles Deleuze in his essays "Control and Becoming" and "Postscript on Control Societies" (Deleuze 1995). Attributing the diagnosis of this historical transition to Foucault, Deleuze writes:

"We're definitely moving toward control societies that are no longer exactly disciplinary. [W] e're moving toward control societies that no longer operate by confining people but through continuous control and instant communication" (Deleuze 1995, 174). The relation one can draw between control societies and an investment in re-enactments and archiving may be found in Deleuze's observation that "In disciplinary societies you were always starting all over again (as you went from school to barracks, from barracks to factory), while in control societies you never finish anything" (179). This endlessness would drive all production (including cultural productions) in control societies to be "directed at metaproduction" (I8I). In this way, we can understand the problematic posed by Burt in relation to re-enactments and dance in control societies.

5. Despite the differences between Santone's and Foster's approaches, it should be noted that psychoanalytically speaking, "drive" and "impulse" are one and the same term (Laplanche and Pontalis 1974, 214), which unites both approaches once again back to the psychological (or the meta-psychological) as privileged critical frames of artistic practices.

6. E-mail correspondence with the author, February 2010.

7. "The virtual is not actual, but as such possesses a reality" (Deleuze r99I, 96).

8. On Spinoza's notion of body see Deleuze (2001) and Deleuze and Guattari (1987, chap. 10).

9. E-mail correspondence with the author, 2009 .

10. All quotes from Nachbar are from a text provided by him to the author containing the English translation of his lines throughout Urbeben Aufheben.

II. "We can speak of events only as singularities deployed in a problematic field, in the vicinity of which the solutions are organized" (Deleuze 1990, 56).

I2 Which means that a plane of composition is a "unit," which is not a "one."

\section{Works Cited}

Agnew, Vanessa. 2007. “History's Affective Turn: Historical Reenactment and Its Work in the Present." Retbinking History II (3): 299-3I2.

Benjamin, Walter. 1996. "The Task of the Translator."In Walter Benjamin: Selected Writings. Volume I, rgr3-1926. Edited by M. Bullock and M. W. Jennings. Cambridge, MA: Belknapp Press of Harvard University Press.

Benso, Silvia. 2000. The Face of Things. Albany: SUNY Press.

Brandstetter, Gabriele. 200o. "Choreography as Cenotaph." In ReMembering the Body: [on the occasion of the exbibition "STRESS" at the MAK, Vienna], edited by Gabriele Brandstetter and Hortensia Vèolckers; with STRESS, an image-essay by Bruce Mau; with texts by André Lepecki; Translated by Andrea Scrima and Rainer Emig. Ostfildern-Ruit: Hatje Cantz.

Burt, Ramsay. 2003. "Memory, Repetition and Critical Intervention: The Politics of Historical Reference in Recent European Dance Performance." Performance Research 8 (2): 34-4I.

Deleuze, Gilles. 1990. The Logic of Sense. European Perspectives. New York: Columbia University Press. Books.

- 1993. The Fold. Translated by T. Conley. Minneapolis: University of Minnesota Press.

- 1995. Negotiations. New York: Columbia University Press.

. 200I. Spinoza: Practical Pbilosophy. San Francisco: City Lights. 
- 2006. Nietzsche and Philosophy. New York: Columbia University Press.

Deleuze, Gilles, and Felix Guattari. 1987.A Thousand Plateaus: Capitalism and Schizopbrenia. London: Athlone.

Deleuze, Gilles, and David Lapoujade. 2006. Two Regimes of Madness: Texts and Interviews 19751995. New York and Cambridge, MA: Semiotext(e), distributed by MIT Press.

Derrida, Jacques. 1995. Archive Fever. Translated by E. Prenowitz. Chicago: University of Chicago Press.

Foster, Hal. 2004. "An Archival Impulse." October (Iro): 3-22.

Foucault, Michel. 1972. The Archaeology of Knowledge. Translated by A. M. S. Smith. New York: Pantheon.

Franko, Mark. 1989. "Repeatability, Reconstruction and Beyond." Theatre Journal $4 \mathrm{I}(\mathrm{x}): 56-74$.

Gordon, Avery. 1997. Ghostly Matters: Haunting and the Sociological Imagination. Minneapolis: University of Minnesota Press.

Harris, William. 1998. "Dragging Martha Back from the Dead." New York Times, December 6, Io.

Laplanche, J., and J.-B. Pontalis. 1974. The Language of Psychoanalysis. New York: W. W. Norton.

Louppe, Laurence. 1994. Traces of Dance: Drawings and Notations of Choreographers. Paris: Editions Dis Voir.

Massumi, Brian. 2002. Parables for the Virtual. Durham, NC: Duke University Press.

Rosenthal, Stephanie. 2008. "Agency for Action."In Allan Kaprow: Art as Life, edited by E. MeyerHermann, A. Perchuk, and S. Rosenthal. Los Angeles: Getty Research Institute.

Santone, Jessica. 2008. “Marina Abramovic's Seven Easy Pieces: Critical Documentation Strategies for Preserving Art's History." Leonardo 4I (2): I47-52.

Schneider, Rebecca. 200I. "Archives Performance Remains." Performance Research 6 (2): 100I08.

Schwartz, Selby Wynn. 2oro. "Martha@Martha: A Séance with Richard Move." Women and Performance: A Journal of Feminist Theory 20 (I): 6I-87.

Taylor, Diana. 2003. The Archive and the Repertoire: Performing Cultural Memory in the Americas. Durham, NC: Duke University Press. 